\title{
Conceptualising climate change adaption for native bush food production in arid Australia
}

\begin{tabular}{l|c}
$\begin{array}{l}\text { Supriya Mathew } \\
\text { Charles Darwin University } \\
\text { supriya.mathew@cdu.edu.au }\end{array}$ & $\begin{array}{c}\text { L.S. Lee } \\
\text { CRC for Remote Economic Participation \& } \\
\text { Southern Cross University } \\
\text { slade.lee@scu.edu.au }\end{array}$ \\
The Australian National University \\
digby.race@anu.edu.au
\end{tabular}

Keywords: climate change adaptation; arid Australia; arid zone lifestyles; native bush food; farming enterprises

\begin{abstract}
Climate projections indicate an average rise in temperature in the range of $3-7^{\circ} \mathrm{C}$ for central Australia by 2100 and a decline in thermal comfort. There is uncertainty in the future spatial and temporal occurrences of extreme events such as floods and droughts, though heat stress is predicted to become more frequent in central Australia. To a large extent, sustainable development in this region aims to create self-sufficient and vibrant remote desert-based communities. In this paper, we examine the prospects for sustaining native bush food production in central Australia under a changing climate. Harvesting of native plants for bush food has strong relevance in a central Australian context, where many bush foods have cultural significance to Aboriginal peoples. The native bush food industry is also important in central Australia as it provides employment for local people and sustains the knowledge and practice associated with culturally significant plants. However, the projections of climate change in the region suggest an increasing risk - to plant production, workers' safety, and getting product to markets. A pathway of the potential steps needed for adaptation (i.e. adaptive pathway) is conceptualised in this paper as to how native bush food production can become a climateready and enduring industry in central Australia.
\end{abstract}

\section{Introduction}

More than 41,000 small to medium sized enterprises operate across Australia's arid or desert region, of which 500 are Aboriginal-owned and around 100 are community controlled art centres (Race, 2015). The bush food industry is also one such emerging business activity which also involves Aboriginal people. Arid Australia is also home to numerous Aboriginal communities involved in the customary harvest of bush food resources and who have extensive knowledge regarding the harvesting and use of bush foods. The Australian bush food market system thus includes harvesting by Aboriginal communities within a customary law system that negotiates specific rights and responsibilities, and also harvesting by non-Aboriginal bush food enterprises working within the framework of Western laws and aim to maximise financial returns (see Merne Altyerre-ipenhe Reference Group, Douglas \& Walsh, 2011). 
The Australian bush food industry is small compared to other agricultural pursuits, but it makes a valuable contribution, both financially and culturally, to people living in arid parts of Australia (see Figure 1 for arid and semiarid regions in Australia). There are no reliable estimates for the total value of the bush food industry in this part of the continent; however it would represent a considerable part of the $\$ 18.5 \mathrm{M}$ industry that employs $500-1,000$ people. Moreover, this value is increased five-fold following processing, which most raw bush food products undergo (Clarke, 2012) before they reach their largely metropolitan markets. The bush food products derived primarily from remote arid regions include bush tomato (estimated annual farm gate value of $\$ 540 \mathrm{~K})$, Kakadu plum $(\$ 240 \mathrm{~K})$, desert lime $(\$ 225 \mathrm{~K})$, quandong $(\$ 180 \mathrm{~K})$ and wattle seed (\$150K) (Clarke, 2012).

The impact of climate change is no less an issue for the Australian native bush food industry than for other sectors of agricultural enterprise. However, as the industry is based on native plants that have evolved to suit the wide range of environments found throughout Australia, the native bush food industry presents some atypical situations and opportunities in regard to climate change adaptation. The aim of this paper is to conceptualise potential adaptation strategies for native bush food production under the changing climate of the arid region of central Australia. We refer to adaptation of the bush food industry with and without the involvement of Aboriginal communities here.

Figure 1: Australian arid zone

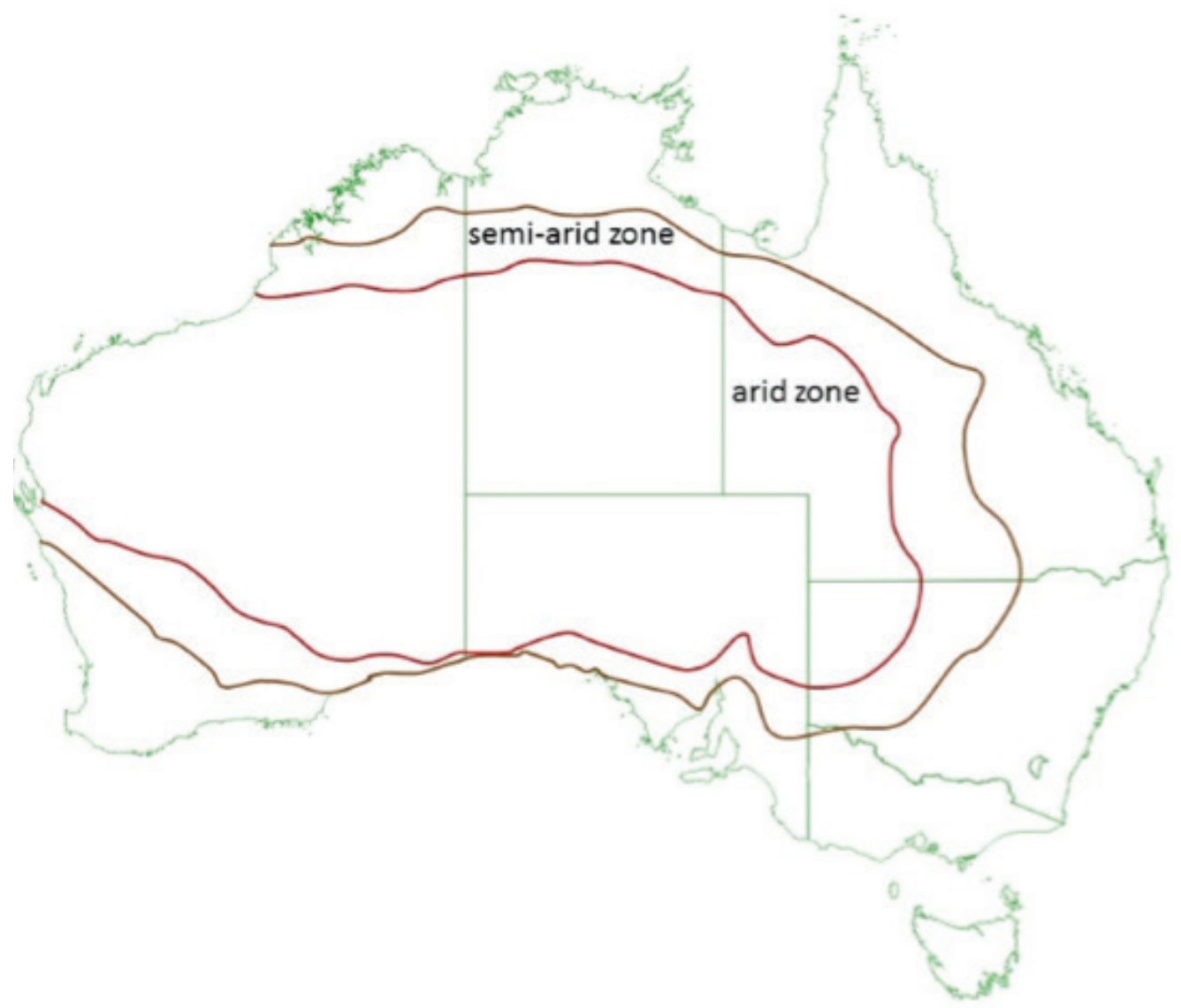

Source: L.S. Lee $\odot$, CRC for Remote Economic Participation, 2015 


\section{Climate projections and bush food production in the Australian arid region}

In the arid region of central Australia, climate model outputs show high confidence in the projection of meteorological parameters such as temperature and extreme heat events. (CSIRO \& Bureau of Meteorology, 2015a). However, the magnitude and direction in which rainfall may vary for central Australia is uncertain (CSIRO \& Bureau of Meteorology, 2015a). In particular, potential changes to future summer rainfall remain unclear, though projections indicate a decline in winter rainfall in the southern parts of central Australia. Whereas in far north-western Australia, there has been a trend of increasing rainfall in the past century, in the south of the continent there has been a slight average decrease (CSIRO \& Bureau of Meteorology, 2014) and the projection is this will continue, which necessitates contingencies for water management planning (Qureshi et al., 2013). There is high confidence in increases in the intensity of extreme rainfall events and medium confidence in the increase in the duration of droughts for the arid parts (CSIRO \& Bureau of Meteorology, 2015a).

Probably of greater impact on climatic conditions will be increasing temperatures. This has been significant over the last hundred years and is projected to continue, with the greatest increases being recorded in central Australia, central and western Queensland, and southwest of Western Australia (CSIRO \& Bureau of Meteorology, 2014; Race, 2015). The climate projections provided by CSIRO and the Bureau of Meteorology (BoM) (2015a) for the remote regions of Australia indicate increasing average temperatures, more hot days, more warm spells and fewer frosts. The duration of warm spells and frequency of hot days will also increase. This also means locations such as Alice Springs, even for an intermediate emission scenario, daily temperatures above $35^{\circ} \mathrm{C}$ could occur for more than a third of the year by 2100 .

Locations within remote Australia will continue to be susceptible to frequent extreme precipitation (high confidence), extended droughts (medium confidence), increased average and maximum temperatures (high confidence) and increased evapotranspiration (high confidence) (CSIRO \& Bureau of Meteorology, 2015a). The uncertain rainfall determines fuel availability for bushfires and hence fire projections are also uncertain. The locations in this region are at risk to the uncertainty associated with periods of water surplus and water deficits. Thus, successful adaptive strategies for the bush food industry also requires successful managing of such uncertainties. The greatest concern in recent times, as results of more detailed analysis emerge, is the increased variability in climate events and the greater unpredictability in forecasting (Anwar et al., 2013; Thornton et al., 2014). Numerous principles and strategies are being used to manage uncertainty and inform adaptation decisions.

\section{Managing climatic uncertainties: principles and strategies}

The climate change adaptation literature discusses a number of ways to manage uncertainty. Responses to climatic changes can be broadly considered to be incremental (adjustments made to meet current objectives under a changed environment where the change is gradual and happens at a certain degree of certainty) and transformational (fundamental changes to the objectives made to meet new or unanticipated abrupt changes) (Stafford Smith et al., 2011). Hallegatte (2009) discusses five principles to managing risk, which includes:

i. 'no-regret' strategies that deliver benefits even in the absence of the impacts of climate change (e.g. options with co-benefits such as local employment for vulnerable communities, see Mathew Trueck \& Henderson-Sellers, 2012);

ii. reversible and flexible options (e.g. options that can cater to new climatic information); 
iii. options with safety margins (e.g. high cost new constructions such as dams to be upgradable considering climatic projections);

iv. soft adaptation options (e.g. community awareness programs; building social capital); and

v. reducing decision time horizons (e.g. options with shorter lifetimes).

These five principles support the adaptive management approach, where monitoring is followed by actions and decisions reviewed in light of new information. Actions that aim to reduce the risks posed by climatic changes whilst also having other additional social (e.g. improved health and well-being), economic (e.g. increased employment opportunities) and environmental (e.g. greenhouse gas reduction) benefits can be chosen using combinations of the above five principles.

Adaptation plans must address contexts of change (e.g. change of societal values and requirements, technological advancements) and uncertainty (e.g. uncertainties in climate projections, uncertainty in local impacts) (see Bosomworth et al., 2015). Recent adaptation research broadly uses the adaptation pathways approach (and its alterations) to decisionmaking under uncertainty. The adaptation pathways approach presents a sequence of actions after a tipping point (usually defined based on different stakeholder/community values, world views, cultural perspectives) beyond which any of the current actions stop meeting the required objectives (see Moss \& Martin, 2012; Haasnoot et al., 2012; Haasnoot et al., 2013; Wise et al., 2014). The adaptation pathways approach considers a diverse range of futures and examines the robustness (insensitivity to changing conditions) and flexibility (easily adaptable) of options across these futures (Bosomworth, 2015). Adaptation pathways assist in avoiding 'lock ins' (see Wilson, 2014) and support the adaptive management approach which includes an iterative decision-making process of acting, monitoring and revisiting decisions (Willows \& Connell, 2003). Some analysts (Wise et al., 2014) adopt a broader approach highlighting societal change aspects of adaptation, which also implies the need for longer term strategies and transformational change. The adaptive pathways approach thus creates a pathway of flexible adaptation options evaluated against short and medium term objectives to ensure the long term adaptation objectives are achieved.

\section{Climate change adaptation in native bush food industries in the arid zone}

The bush food industry is at risk from annual cycles of weather changes, increasing atmospheric temperature and occurrences of low probability high impact events (see Figure 2), and will need various strategies to adapt to the potential risks. In this section, we first explore general adaptation strategies for crop production and wild harvest in arid Australia. Secondly, we use the adaptive pathways framework and the five principles of managing risk to conceptualise contextually relevant and potential adaptation strategies for the native bush food industry in the arid zone (also see Table 1). 
Figure 2: The impact of climate change on a small scale bush plant business operated by Aboriginal communities.

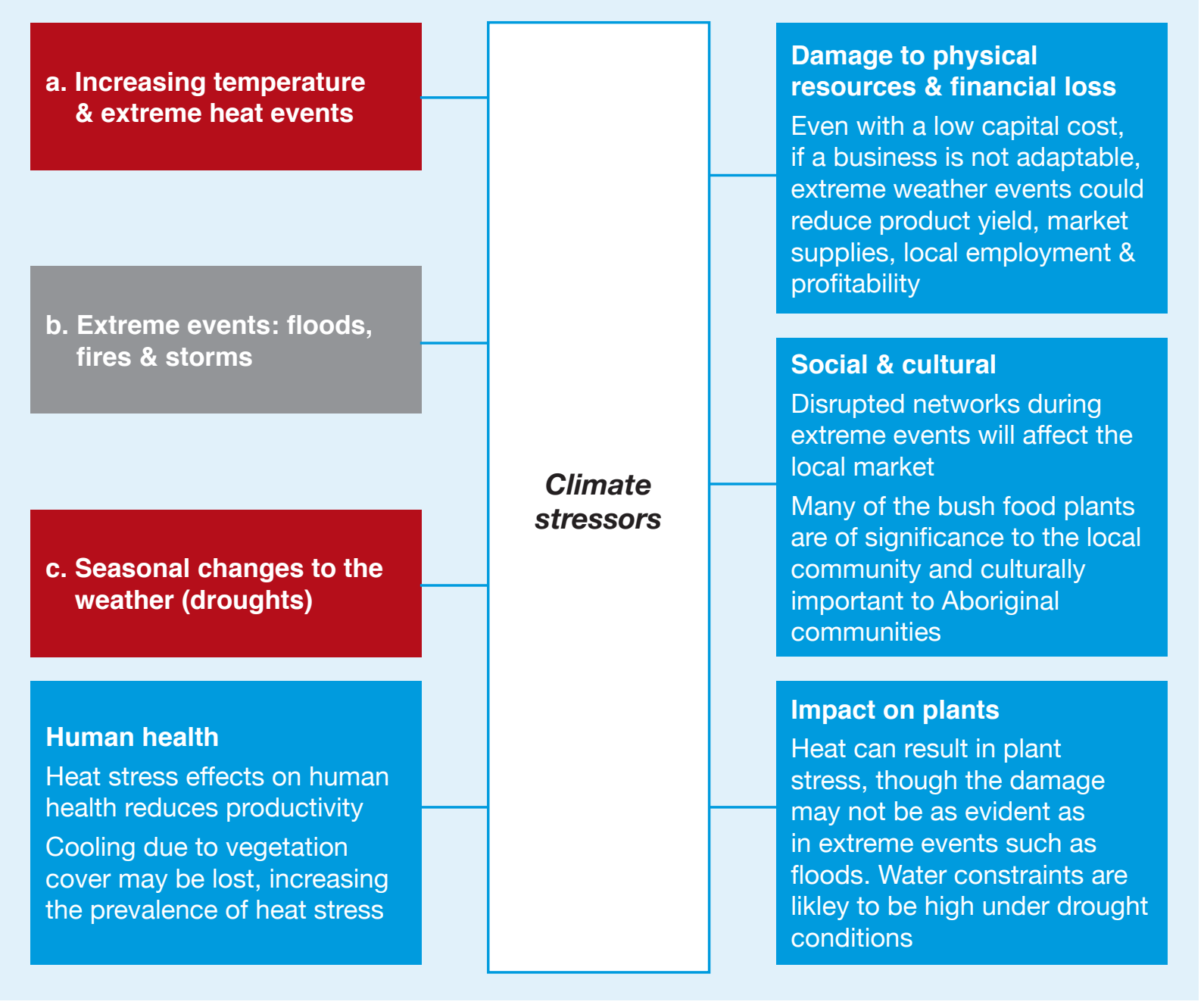

Note: Red shapes indicate highly certain climate stressors and the grey indicates less certain climate stressors. The blue boxes represent potential risks posed on the bush food business. 


\begin{tabular}{|c|c|c|}
\hline 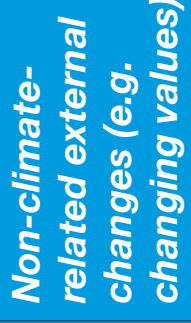 & 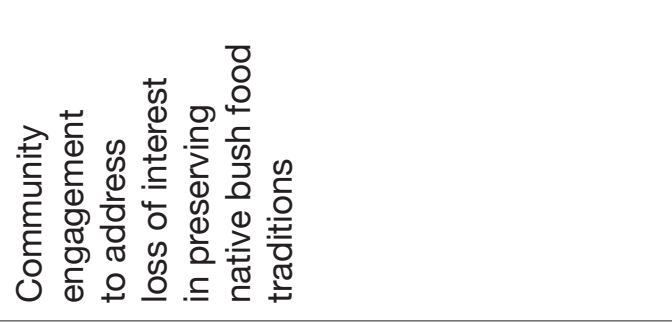 & 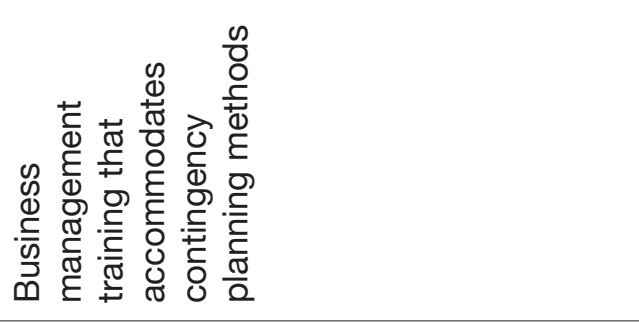 \\
\hline 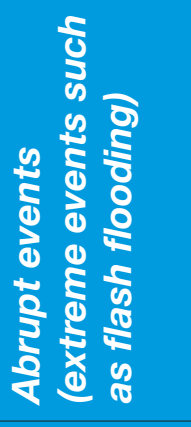 & 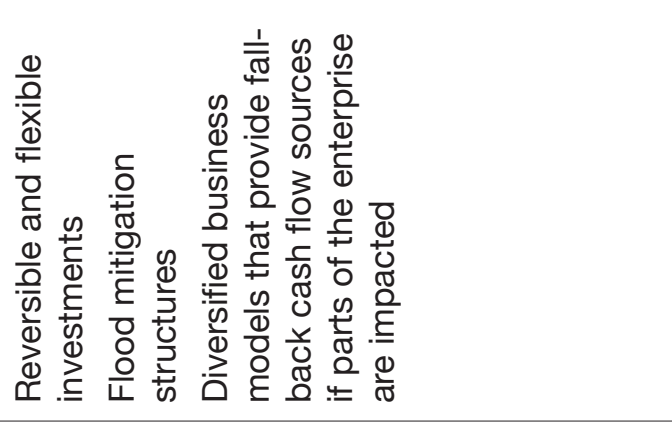 & 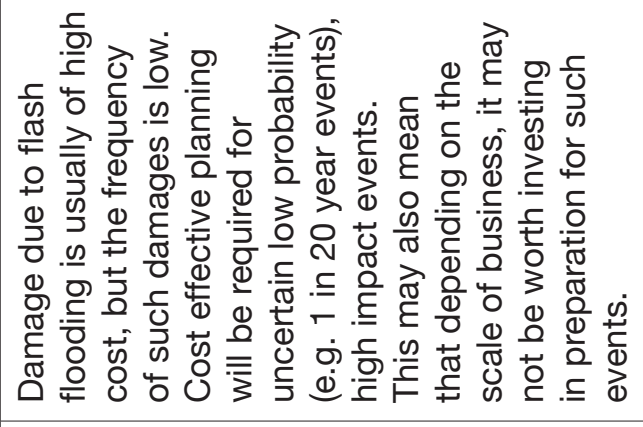 \\
\hline 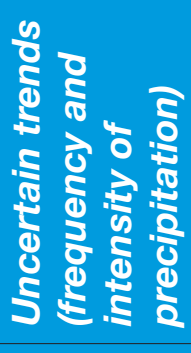 & 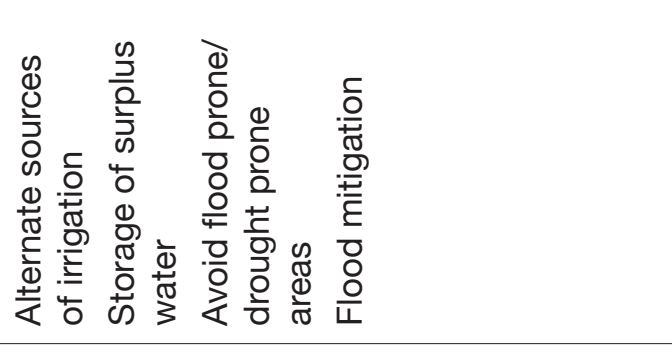 & 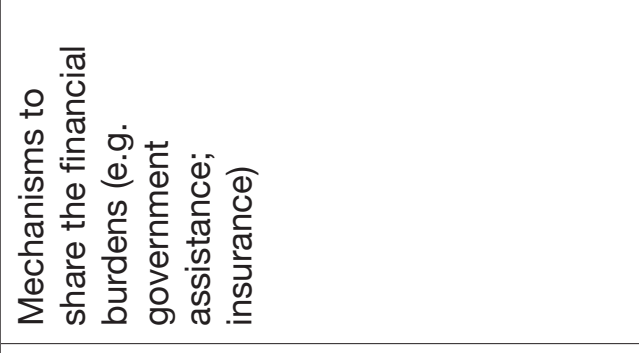 \\
\hline 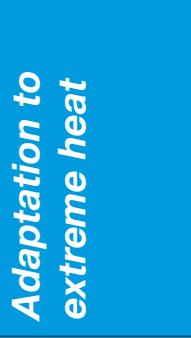 & 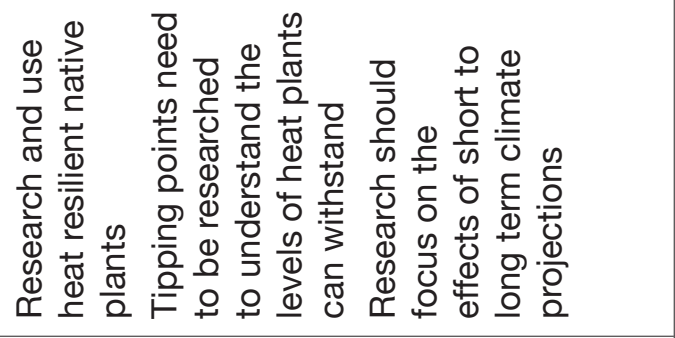 & 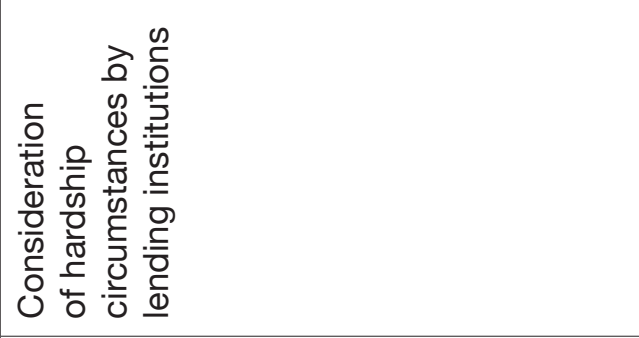 \\
\hline 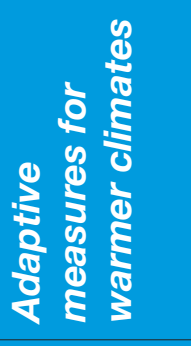 & 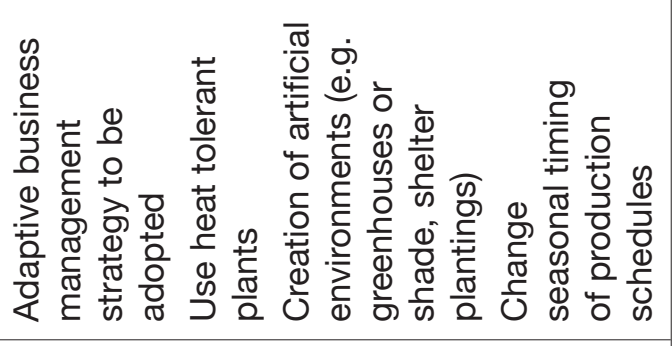 & 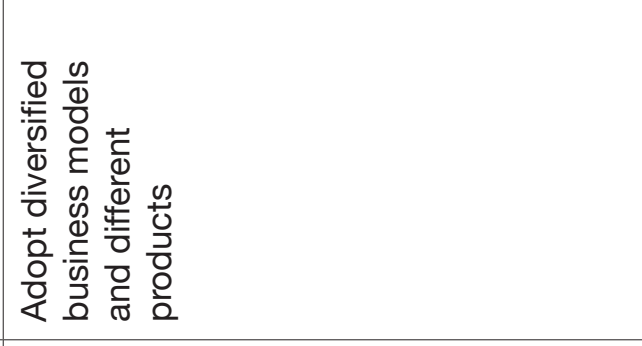 \\
\hline 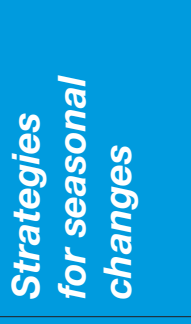 & 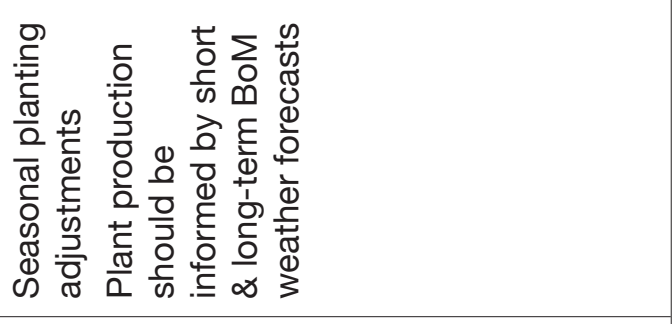 & 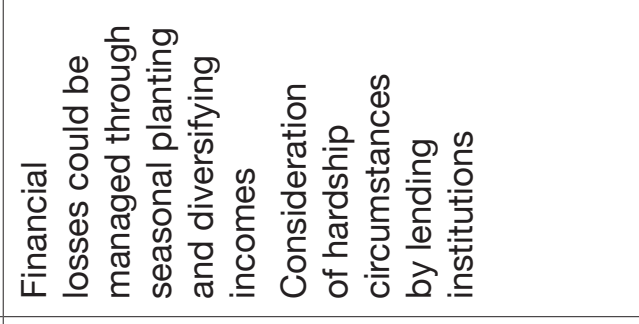 \\
\hline & 灾 & 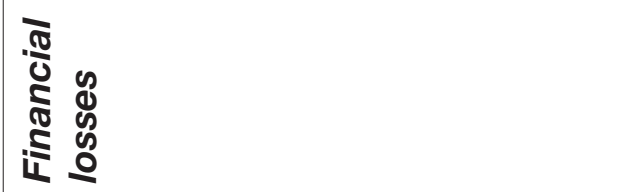 \\
\hline
\end{tabular}




\begin{tabular}{|c|c|}
\hline 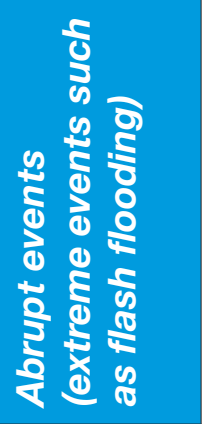 & 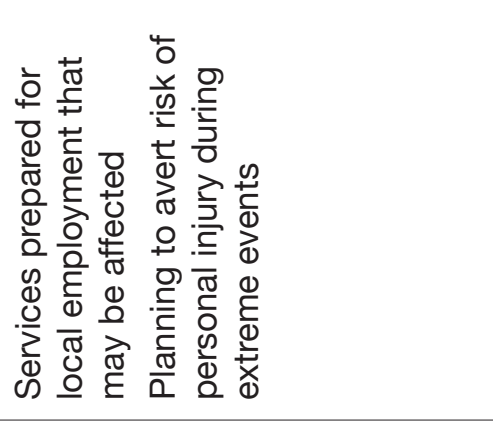 \\
\hline 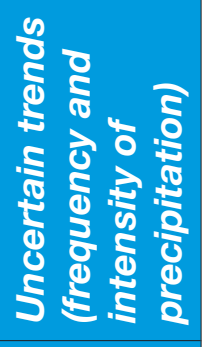 & 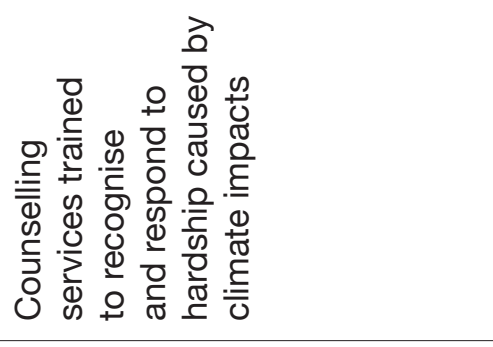 \\
\hline 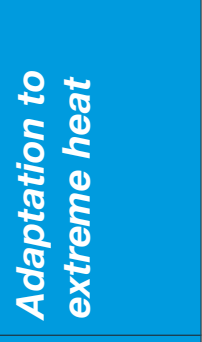 & 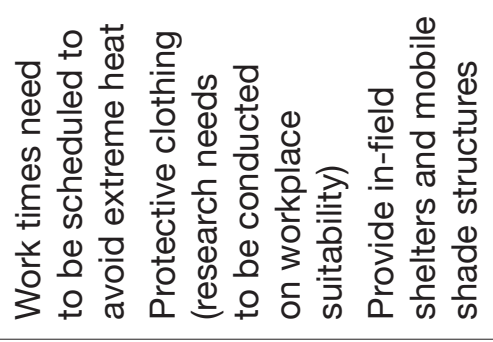 \\
\hline 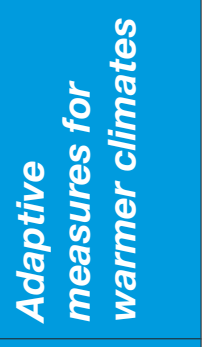 & 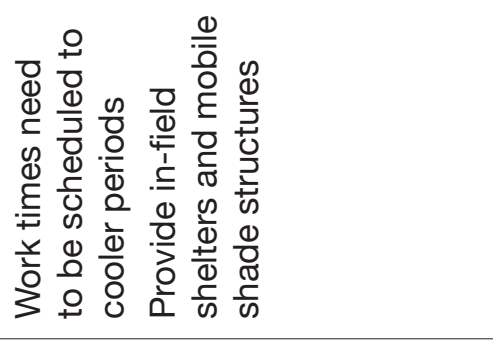 \\
\hline 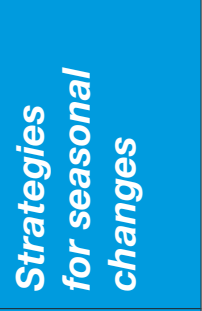 & 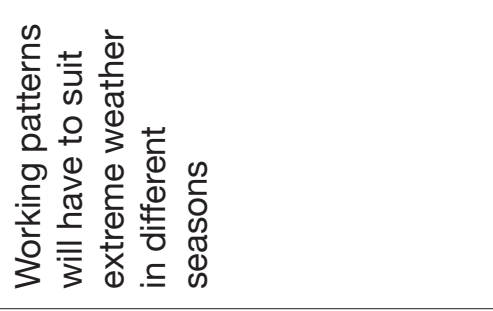 \\
\hline & 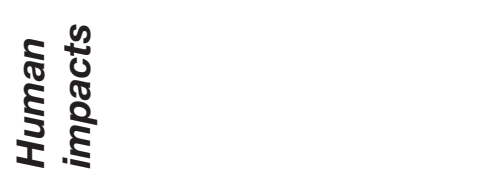 \\
\hline
\end{tabular}




\section{Crop production}

While at first it appears climate change can only be problematic for Australian agriculture in the arid zone, it is however, quite possible some positive outcomes could result. For instance, the prediction rainfall should not decrease, and indeed may slightly increase in some parts of arid Australia, indicates crop production opportunities may not necessarily decline due to a diminishing water supply. Thus, it seems, with appropriate adaptation strategies the maintenance of dryland agriculture, and even its possible expansion, could be a reality. Moreover, potential new opportunities are envisaged as part of the response to climate change.

The resilience of agricultural systems in the face of changing climate, at a global scale will call upon regional and local strategies of coordinated approaches involving the sustainable use of soil and water resources, agro-forestry, farming systems diversification, modified cultivation practices, the use of stress-tolerant crops and genetic improvement (Mijatovic et al., 2013). These authors argue effective adaptation strategies will be integrated with combined resiliencestrengthening practices at different scales: (i) the landscape level, (ii) farming systems, and (iii) species/varieties. Central to this proposition, is the utilisation of agricultural biodiversity and the long experience of traditional agricultural communities in adapting their social and production systems to accommodate environmental challenges (Vigouroux et al., 2015). Through the natural response processes of adaptive genetic diversity, many crop species will be self-selective in the face of environmental change (Dudley, 1996), thus influencing the genetic resources to which researchers and plant breeders will have access in order to help agricultural communities adapt. These response mechanisms include phenotypic plasticity, genetic selection, gene flow and extinction (Mercer \& Perales, 2010).

Plants have evolved a wide range of physiological and physical mechanisms to deal with drought and heat stress (Lipiec et al., 2013) including root growth responses, reduced transpiration and photosynthesis, greater water use efficiency, and production of defensive compounds and proteins. For astute plant breeders and researchers, opportunities will be presented as a result of environmental change. Some authors point to the opportunity for taking advantage of productivity gains from breeding crops responsive to elevated atmospheric CO2 levels (Ziska et al., 2012). Phenotypic assessment of beneficial crop characteristics can be harnessed and the use of biotechnology for genetic improvement to adapt to changing climate, and even the identification of geographic relocation options, are all being investigated (Chapman et al., 2012) to tackle emerging challenges, including more frequent and longer droughts, waterlogging, salinity and changing pest and pathogen pressures. However, geographic relocation of bush plants may not be a viable option for wild harvest as this practice is often linked to dreaming, country and people (Merne Altyerre-ipenhe Reference Group et al., 2011).

Ultimately, production of conventional crops is limited by water requirements and their levels of heat tolerance. Provision of irrigation, planting of appropriate crop types and selection of suitable varieties help to achieve production in marginal areas, where these approaches fit the prevailing conditions. Nonetheless, crop production opportunities in the arid zone are largely constrained by environment. An opportunity exists, however, in cropping enterprises based on the very plants that have adapted and evolved in this environment. In their current state, such native plants exhibit particular resilience in coping with harsh conditions. The bush tomato or desert raisin (Solanum centrale) is a case in point where a lucrative, albeit small, farming industry is developing (Lee, 2012) in central Australia (Figure 3). Another example is Kakadu plum or gubinge (Terminalia ferdinandiana) which shows potential for developing into a major crop for northern Australia (Cunningham, Garnett, Gorman, Courtenay \& Boehme, 2009) growing closer to the coast, marked by a prolonged dry season. Others that already show some level of market demand include Australian native lemongrass (Cymbopogon ambiguus), Old Man 
saltbush (Atriplex nummularia), desert lime (Citrus glauca), wattle seed (predominantly Acacia victoriae, but also other arid acacias (Figure 4) A. aneura, A. colei, A. coriacea, A. murrayana, and $A$. pycnantha), quandong (Santalum acuminatum) and sandalwood (Santalum spicatum). All are highly adapted to arid environments and are expected to tolerate changing climatic conditions easily.

Naturally, genetic improvement for climate change adaptation is far more prevalent in conventional crop species (Chapman et al., 2012; Ziska et al, 2012). However, the very nature of the variable environment in which Australian species of the arid zone have evolved furnishes them with adaptive capacity to withstand occasional severe conditions. That characteristic presents two advantages - firstly, the resilience to accommodate the anticipated future thermal changes, and secondly, the genetic resources to facilitate selection and plant breeding for better adapted varieties. Such research has already occurred for saltbush (Atriplex spp.) (Joseph et al., 2013), native pasture grasses (Reed et al., 2008), and native legumes (Bennett et al., 2011).

In another approach, biotechnology is being harnessed in the form of 'xenogenomics' to discover genes in Australian native species that confer tolerance to drought and adverse soil conditions that may result from an increasingly hostile climate (John \& Spangenberg, 2005). Such work offers the dual potential of advancing the understanding of abiotic stress tolerance physiology and identifying candidate genes for introgression into crops to confer climate change adaptation. In field situations, adaptive characteristics of native plants under adverse growing conditions are being investigated, initially with species for pasture management (Nie et al., 2008; Reed et al., 2008), aimed at facilitating genetic improvement. This is paving the way for greater understanding of the contribution that endemic plant species can make to climate change adaptation for crops in the arid regions.

Further, while the adoption of new arid-adapted crops presents a novel approach to creating productive farming enterprises resilient to climate change in Australia's arid region, complementary strategies involving novel production concepts are also being explored. Such techniques as 'minimum till' cultivation (Tang \& Zhang, 1996; Bauer et al., 2010) or an even more radical approach of 'enrichment planting' (Lee \& Courtenay, 2016) are examples of innovative thinking applied to arid zone crop production systems that, among other benefits, impart enhanced resilience against climate change in harsh environments. 
Figure 3: Solanum centrale distribution

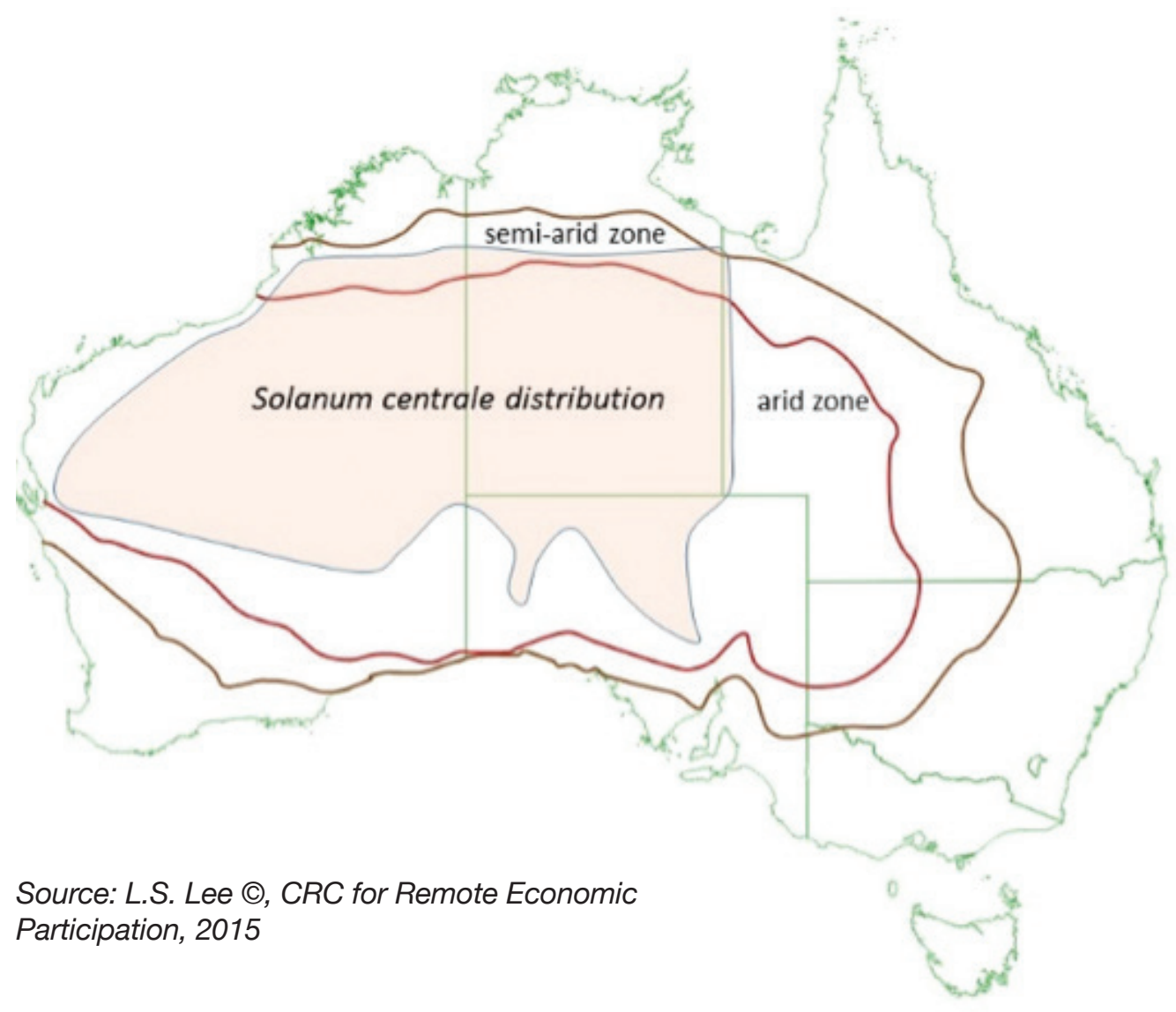

Figure 4: Arid Acacia species distribution

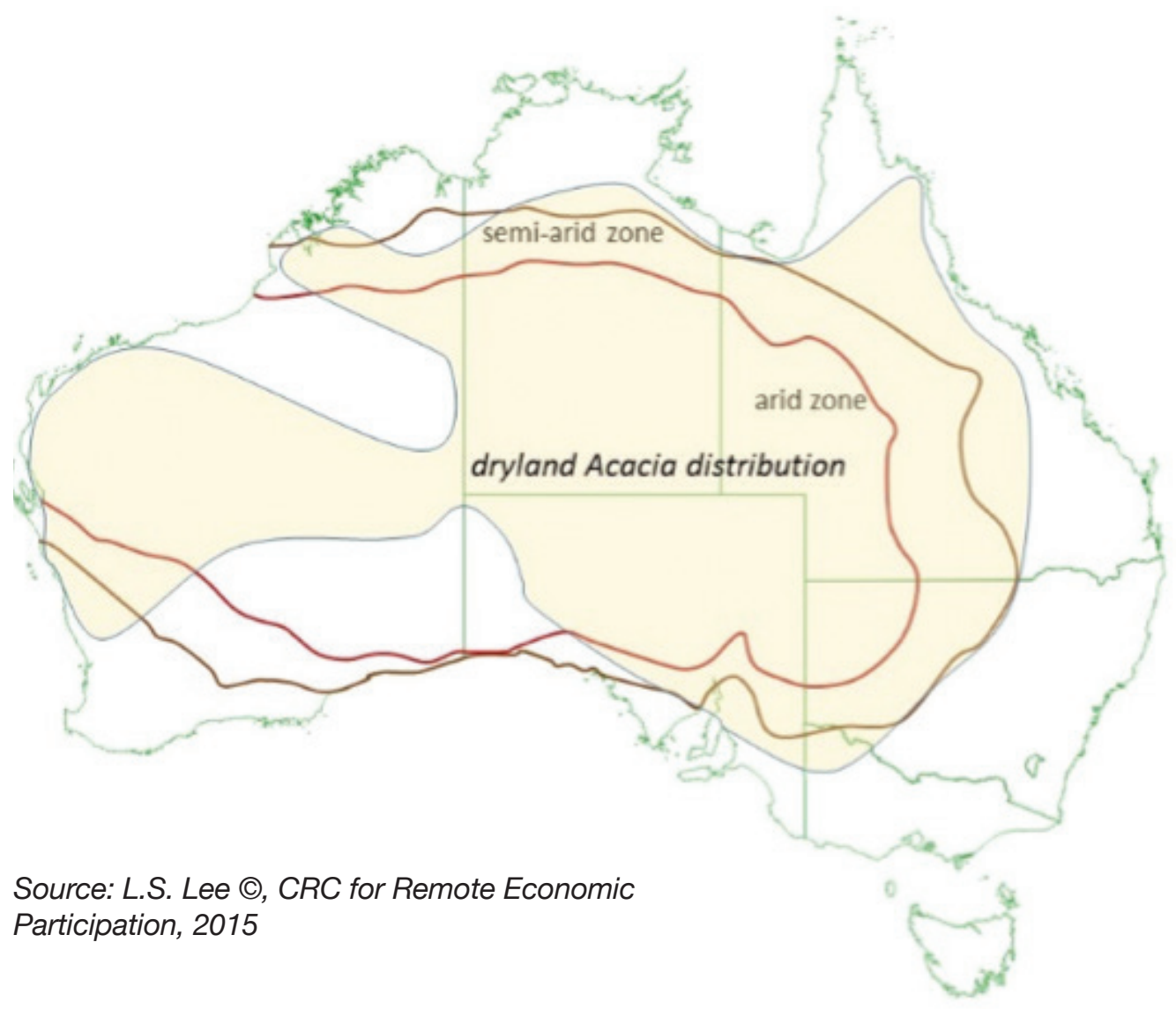




\section{Wild harvest}

A significant counterpart to bush food production in cropping systems of various kinds, is the complementary activity of wild harvesting. On average, approximately half of the annual production of bush tomato and wattle seed comes from wild harvesting, and a much higher proportion in good years (Clarke, 2012), and arguably (depending on whether enrichment plantings are considered crops or wild) almost the entirety of Kakadu plum is wild harvested (Lee \& Courtenay, 2016). Moreover, wild harvesting practice plays an extremely important social and cultural role in Aboriginal and Torres Strait Island communities (Alyawarr speakers from Ampilatwatja, Walsh \& Douglas, 2009; Merne Altyerre-ipenhe Reference Group et al., 2011; Lee, 2012; Walsh et al., 2013). This vital part of the bush food supply chain is almost exclusively undertaken by Aboriginal and Torres Strait Islander people, and as Race (2015) points out, climate change will present even more arduous conditions for such activities in future years. It is anticipated wild harvest will continue to play a significant role in the bush foods industry, and climate change will necessitate amendments to current practices. Fortunately, advancing technology such as improved communication services, reliable air conditioned vehicles, electricity and refrigeration in remote locations will help to alleviate the conditions for workers and assist in maintaining post-harvest bush food product quality.

\section{Managing risks associated with climatic changes}

In this sub-section, we conceptualise a pathway of flexible adaptation options that may be evaluated against short and medium term objectives to ensure the long term adaptation objective of developing a sustainable native bush food industry in arid Australia is achieved. Cost effective incremental options may be preferred over high cost transformational adaptation that specifically focus on the native bush food industry. This is mainly because climate change risks are not limited to the bush food or agriculture industry in central Australia. Adaptation is thus required by the community and various industries supporting these communities.

Many of the adaptive measures in other sectors as well as within the bush food industry will deliver benefits across sectors. For instance, a number of heat stress related adaptive measures (e.g. uptake of solar technology; energy efficient building designs) have already been piloted in central Australia. Reliable low cost supply of power can facilitate artificial moderation of climate for bush food production reducing stress to the plants and human health and more efficient post-harvest processing. Improved digital communication also provides the opportunity for better networking among remote producers and scientists creating a sharing and learning platform for best practice strategies.

Many of the strategic investments for the long term such as those for managing extreme events are likely to be high cost, and actions will depend on the scale and financial returns from such businesses. In such situations, the bush food industry itself may not be strong enough to trigger transformational changes, but adaptation transformations in other sectors may derive new pathways for the bush food industry. The adaptive capacity of the remote bush food industry is dynamic and also subject to interventions made by other dominant sectors (local and national). Thus in the short to medium term, the bush food industry may benefit by following an adaptive management approach, with decision points determining the nature and path of adaptation. Decision points could be determined by non-Aboriginal business owners (financial value), traditional owners (cultural value) and the community (urban markets and local value of the product). The thresholds (determining decision points) for preserving the cultural value of bush foods are likely to be entirely different from the threshold values that consider the financial or non-Aboriginal local value, unless a loss of interest in preserving native bush food traditions becomes prevalent among Aboriginal communities. Reduced planning times 
could be used as a strategy to manage uncertainties associated with climatic and non-climatic changes and its impacts and benefit from transformative adaptations as more technological advancements happen elsewhere.

An adaptive plan that accommodates seasonal changes, gradually warming atmospheres, extreme heat, uncertain precipitation and floods/droughts is conceptualised for the bush food industry in Table 1. In the table, adaptation strategies are provided that target short/medium term objectives to ensure: i) adaptation of the native bush plants, ii) financial returns from the industry and iii) adaptation by the human capital required for the industry. In general, flexible options (e.g. use of cost effective shades; diversify incomes), 'soft' adaptation options (e.g. utilising adaptive strengths such as the strong social and traditional knowledge capital among Aboriginal communities to enhance networking and communication regarding best practice bush food production) and low regret options (e.g. avoiding flood prone areas) may be favoured in such short planning periods and will also provide opportunities to accommodate change over time (e.g. transformational change) triggered by the requirement of other industries, locations or technological advancements.

\section{Conclusion}

The native bush food industry makes an important cultural and economic contribution to central Australia, and adds to the culinary diversity of menus nationally and internationally. While the industry is expanding, it is still in a consolidation phase in central Australia. The risk of climate change, particularly given the projected rise in average temperatures across Australia's arid central region, has only recently been considered for this industry. The anticipated increase in heat stress will affect both the native plants and the people employed in the industry, with the combined impacts threatening the viability of businesses that adopt a 'business as usual' approach.

Effective climate change adaptation may afford some opportunities for the native bush food industry, such as changing production practices to become more efficient, focussing on species that are suited to hotter conditions, and being more conscious of ensuring employees have comfortable and safe working conditions. Adaptation actions for the central Australian bush food industry will thus be more incremental in nature, but will be subject to transformative adaptation efforts happening in other sectors and at large/urban scales. The threat of climate change may trigger strategic thinking and innovation of a 'learning community' that creates a robust and sustainable industry that becomes well adapted to the increasingly variable conditions of the future.

\section{Acknowledgement}

The work reported in this publication was supported by funding from the Australian Government Cooperative Research Centres Program through the Cooperative Research Centre for Remote Economic Participation (CRC-REP). The views expressed herein do not necessarily represent the views of the CRC REP or Ninti One Limited or its participants. Errors or omissions remain with the author. We also wish to acknowledge Ninti One for providing the resources to fund this Special Issue as well as the Northern Institute, at Charles Darwin University for providing the opportunity for publication. 


\section{References}

Adams, R.M., Hurd, B.H., Lenhart, S., \& Leary, N. (1998). Effects of global climate change on agriculture: an interpretative review. Climate Research, 11, 19-30.

Aguiar, A.C. (2012). Urban heat islands differentiating between the benefits and drawbacks of using native or exotic vegetation in mitigating climate. Master of Science (Research) Thesis. Wollongong, NSW :School of Biological Sciences, University of Wollongong. Retrieved from http://ro.uow.edu.au/cgi/viewcontent.cgi?article=4755\&context=theses on 30/07/2915

Al Dosery, N., Mathew, M., Suresh, N., \& Al-Menaie, H.S. (2012). Kuwait's agricultural efforts to mitigate climate change. Energy Procedia, 18, 1441-1445.

Altieri, M.A., Nicholls, C.I., Henao, A., \& Lana, M.A. (2015). Agroecology and the design of climate change-resilient farming systems. Agronomy for Sustainable Development, 35(3), 869-890.

Alyawarr speakers from Ampilatwatja, Walsh, F., \& Douglas, J. (2009). Angka Akatyerr-akert: A Desert Raisin Report. Alice Springs, NT: Desert Knowledge Cooperative Research Centre. Retrieved from http://www.desertknowledgecrc.com.au/resource/AngkaAkatyerrAkert/index.html

Anwar, M.R., Liu, D.L., Macadam, I., \& Kelly, G. (2013). Adapting agriculture to climate change: a review. Theoretical and Applied Climatology, 113, 225-245.

Bauer, P.J., Fortnum, B.A., \& Frederick, J.R. (2010). Cotton responses to tillage and rotation during the turn of the century drought. Agronomy Journal, 102(4), 1145-1148.

Bennett, R.G., Ryan, M.H., Colmer, T.D., \& Real, D. (2011). Prioritisation of novel pasture species for use in water-limited agriculture: a case study of Cullen in the Western Australian wheatbelt. Genetic Resources and Crop Evolution, 58(1), 83-100.

Boomiraj, K., Wani, S.P., Garg, K.K., Aggarwal, P.K., \& Palanisami, K. (2010). Climate change adaptation strategies for agro-ecosystem - a review. Journal of Agrometeorology, 12(2), 145-160.

Bosomworth, K., Harwood, A., Leith, P., \& Wallis P. (2015). Adaptation pathways: a playbook for developing options for climate change adaptation in natural resource management. Southern Slopes Climate Change Adaptation Research Partnership (SCARP): RMIT University, University of Tasmania, and Monash University.

Calzadilla, A., Zhu, T., Rehdanz, K., Tol, R.S.J., \& Ringler, C. (2014). Climate change and agriculture: Impacts and adaptation options in South Africa. Water Resources and Economics, 5, 24-48.

Chakraborty, S. (2013). Migrate or evolve: options for plant pathogens under climate change. Global Change Biology, 19(7), 1985-2000.

Challinor, A.J., Ewert, F., Arnold, F., Simelton, E., \& Fraser, E. (2009). Crops and climate change: progress, trends, and challenges in simulating impacts and informing adaptation. Journal of Experimental Botany, 60(10), 2775-2789.

Chapman, S.C., Chakraborty, S., Dreccer, M.F. \& Howden, S.M. (2012). Plant adaptation to climate change-opportunities and priorities in breeding. Crop \& Pasture Science, 63(3), 251-268.

Chen, D. (2013). Greening City - Mitigate Heat Stress with Urban Vegetation. CSIRO report for HAL, Project No. NY11013. Retrieved from http://www.ngia.com.au/FinalReports/NY11013_Greening_ City_-_Mitigate_Heat_Stress_with_Urban_Vegetation.pdf

Clarke, M. (2012). Australian Native Food Industry Stocktake. RIRDC Publication No. 12/066. Canberra, ACT: Rural Industries Research and Development Corporation.. Retrieved from https://rirdc. infoservices.com.au/downloads/12-066

CSIRO \& Bureau of Meteorology. (2014). State of the Climate (2014). Retrieved from http://www.bom. gov.au/state-of-the-climate/documents/state-of-the-climate-2014_low-res.pdf 
CSIRO \& Bureau of Meteorology. (2015a). Climate Change in Australia website. Retrieved from http://www.climatechangeinaustralia.gov.au/en/climate-projections/future-climate/ regional-climate-change-explorer/super-clusters/?current=RA\&tooltip=true\&popup=true

CSIRO \& Bureau of Meteorology. (2015b). Climate Change in Australia website. Retrieved from http:// www.climatechangeinaustralia.gov.au/en/

Cunningham, A., Garnett, S., Gorman, J., Courtenay, K., \& Boehme, D. (2009). Eco-Enterprises and Terminalia ferdinandiana: 'Best Laid Plans' and Australian policy lessons. Economic Botany, 63, 16-28.

Dudley, S.A. (1996). The response to differing selection on plant physiological traits: Evidence for local adaptation. Evolution, 50(1), 103-110.

Easterling, W.E. (1996). Adapting North American agriculture to climate change in review. Agricultural and Forest Meteorology, 80(1), 1-53.

Esham, M., \& Garforth, C. (2013). Climate change and agricultural adaptation in Sri Lanka: a review. Climate and Development, 5(1), 66-76.

Falloon, P., \& Betts, R. (2010). Climate impacts on European agriculture and water management in the context of adaptation and mitigation-The importance of an integrated approach. Science of the Total Environment, 408(23), 5667-5687.

Gupta, R. (2012). Temporal and Spatial Variations of Urban Heat Island Effect in Jaipur City Using Satellite Data Environment and Urbanization Asia, 3(2) 359-374.

Haasnoot, M. Kwakkel, J.H., Walker, W.E., \& Maat, J. (2013). Dynamic adaptive policy pathways: A method for crafting robust decisions for a deeply uncertain world. Global Environmental Change, 23(2), 485-498.

Haasnoot, M., Middelkoop, H., Offermans, A., van Beek, E., \& van Deursen, W.P.A. (2012). Exploring pathways for sustainable water management in river deltas in a changing environment. Climatic Change, 115, 795-819

Hallegatte, S. (2009). Strategies to adapt to an uncertain climate change. Global Environmental Change A, 19(2), 240-247.

Iglesias, A., Erda, L., \& Rosenzweig, C. (1996). Climate change in Asia: A review of the vulnerability and adaptation of crop production. Water Air and Soil Pollution, 92(1-2), 13-27.

John, U.P., \& Spangenberg, G.C. (2005). Xenogenomics: genomic bioprospecting in indigenous and exotic plants through EST discovery, cDNA microarray-based expression profiling and functional genomics. Comparative and Functional Genomics, 6(4), 230-235.

Joseph, S., Murphy, D., \& Bhave, M. (2013). Glycine betaine biosynthesis in saltbushes (Atriplex spp.) under salinity stress. Biologia, 68(5), 879-895.

Juroszek, P., \& von Tiedemann, A. (2015). Linking plant disease models to climate change scenarios to project future risks of crop diseases: a review. Journal of Plant Diseases and Protection, 122(1), 3-15.

Lal, R., Delgado, J.A., Groffman, P.M., Millar, N., Dell, C., \& Rotz, A. (2011). Management to mitigate and adapt to climate change. Journal of Soil and Water Conservation, 66(4), 276-285.

Lamichhane, J.R., Barzman, M., Booij, K., Boonekamp, P., Desneux, N., Huber, L., Kudsk, P., Langrell, S.R.H., Ratnadass, A., Ricci, P., Sarah, J-L. \& Messean, A. (2015). Robust cropping systems to tackle pests under climate change. A review. Agronomy for Sustainable Development, 35(2), 443-459. 
Lee, L.S., \& Courtenay, K. (2016). Enrichment plantings as a means of enhanced bush food and bush medicine plant production in remote arid regions. Learning Communities: International Journal of Learning in Social Contexts, 18.

Lee, L.S. (2012). Horticultural development of bush food plants and rights of Indigenous people as traditional custodians - the Australian Bush Tomato (Solanum centrale) example: a review. The Rangeland Journal 34(4), 359-373.

Leguizamon, E.S., \& Acciaresi, H.A. (2014). Climate change and the potential spread of Sorghum halepense in the central area of Argentina based on growth, biomass allocation and ecophysiological traits. Theoretical and Experimental Plant Physiology, 26(2), 101-113.

Li, R-L., \& Geng, S. (2013). Impacts of Climate Change on Agriculture and Adaptive Strategies in China. Journal of Integrative Agriculture, 12(8), 1402-1408.

Li, Y., Conway, D., Xiong, W., Gaaaao, Q., Wu, Y., Wan, Y., Li, Y., \& Zhang, S. (2011). Effects of climate variability and change on Chinese agriculture: a review. Climate Research, 50(1), 83-102.

Lipiec, J., Doussan, C., Nosalewicz, A., \& Kondracka, K. (2013). Effect of drought and heat stresses on plant growth and yield: a review. International Agrophysics, 27(4), 463-477.

Mathew, S., Trueck, S., \& Henderson-Sellers A. (2012). Kochi, India case study of climate adaptation to floods: ranking local government investment options. Global Environmental Change, 22(1), 308-319.

McMichael, A., Woodruff, R., Whetton, P., Hennessy, K., Nicholls, N., Hales, S., Woodward, A., \& Kjellstrom, T. (2002). Human health and climate change in Oceania: a risk assessment. Canberra, ACT: Australian Government.

Mercer, K.L., \& Perales, H.R. (2010). Evolutionary response of landraces to climate change in centers of crop diversity. Evolutionary Applications, 3(5-6), 480-493.

Merne Altyerre-ipenhe Reference Group, Douglas, J., \& Walsh, F. (2011). Aboriginal People, Bush Foods Knowledge and Products from Central Australia: Ethical Guidelines for Commercial Bush Food Research, Industry and Enterprises, Report 71. Alice Springs, NT: Ninti One Ltd. Retrieved from http://www.nintione.com.au/resource/NintiOneResearchReport_71_Bush foodGuidelines.pdf

Mijatovic, D., Van Oudenhoven, F., Eyzaguirre, P., \& Hodgkin, T. (2013). The role of agricultural biodiversity in strengthening resilience to climate change: towards an analytical framework. International Journal of Agricultural Sustainability, 11(2), 95-107.

Moss, A., \& Martin, S. (2012) Flexible adaptation pathways. Scotland: ClimateXChange. Retrieved from http://www.climatexchange.org.uk/adapting-to-climate-change/flexible-adaptation-pathways/

Nie, Z.N., Miller, S., Moore, G.A., Hackney, B. F., Boschma, S.P., Reed, K.F.M., Mitchell, M., Albertsen, T.O., Clark, S., Craig, A.D., Kearney, G., Li, G.D., \& Dear, B.S. (2008). Field evaluation of perennial grasses and herbs in southern Australia. 2. Persistence, root characteristics and summer activity. Australian Journal of Experimental Agriculture, 48(4), 424-435.

Osborne, T., Rose, G., \& Wheeler, T. (2013). Variation in the global-scale impacts of climate change on crop productivity due to climate model uncertainty and adaptation. Agricultural and Forest Meteorology, 170, 183-194.

Parry, M.L., Rosenzweig, C., Iglesias, A., Livermore, M., \& Fischer, G. (2004). Effects of climate change on global food production under SRES emissions and socio-economic scenarios. Global Environmental Change, 14(1), 53-67.

Potchter, O., \& Ben-Shalom, H.I. (2013). Urban warming and global warming: Combined effect on thermal discomfort in the desert city of Beer Sheva, Israel. Journal of Arid Environments, 98, 113-122. 
Qureshi, M.E., Whitten, S.M., Mainuddin, M., Marvanek, S., \& Elmandi, A. (2013). A biophysical and economic model of agriculture and water in the Murray-Darling Basin, Australia. Environmental Modelling \& Software, 41, 98-106.

Race, D. (2015). The impacts of, and strategies to ameliorate, the intensity of climate change on enterprises in remote Australia. CRC-REP Working Paper CW020. Alice Springs, NT: Ninti One Ltd. Retrieved from http://www.crc-rep.com.au/resource/CW020_ ClimateChangelmpactsOnEnterprises.pdf

Reed, K.F.M., Nie, Z.N., Miller, S., Hackney, B.F., Boschma, S.P., Mitchell, M.L., Albertsen, T.O., Moore, G.A., Clark, S.G., Craig, A.D., Kearney, G., Li, G.D., \& Dear, B.S. (2008). Field evaluation of perennial grasses and herbs in southern Australia. 1. Establishment and herbage production. Australian Journal of Experimental Agriculture, 48(4), 409-423.

Rotter, R.P., Hohn, J.G., \& Fronzek, S. (2012). Projections of climate change impacts on crop production: A global and a Nordic perspective. Acta Agriculturae Scandinavica Section A-Animal Science, 62(4): 166-180.

Rounsevell, M.D.A., Evans, S.P., \& Bullock, P. (1999). Climate change and agricultural soils: Impacts and adaptation. Climate Change, 43(4), 683-709.

Semenov, M.A., \& Shewry, P.R. (2011). Modelling predicts that heat stress, not drought, will increase vulnerability of wheat in Europe. Scientific Reports, 1, 66.

Shepherd, A., Wu, L.H., Chadwick, D., \& Bol, R. (2011). A review of quantitative tools for assessing the diffuse pollution response to farmer adaptations and mitigation methods under climate change. Advances in Agronomy, 112, 1-54.

Stafford Smith, M., Horrocks, L., Harvey, A., \& Hamilton, C. (2011). Rethinking adaptation for a $4^{\circ} \mathrm{C}$ world. Philosophical Transactions of the Royal Society A, 369(1934), 196-216.

Tang, K., \& Zhang, C.E. (1996). Research on minimum tillage, no-tillage and mulching systems and its effects in China. Theoretical and Applied Climatology, 54(1-2), 61-67.

Teixeira, E.I., Fischer, G., van Velthuizen, H., Walter, C., \& Ewert, F. (2013). Global hot-spots of heat stress on agricultural crops due to climate change. Agricultural and Forest Meteorology, 170, 206-215.

Thornton, P.K., Ericksen, P.J., Herrero, M., \& Challinor, A.J. (2014). Climate variability and vulnerability to climate change: a review. Global Change Biology, 20(11), 3313-3328.

Vaneckova, P., Beggs, P., De Dear, R., \& McCracken, K. (2008). Effect of temperature on mortality during the six warmer months in 2004. Environmental Research, 108(3), 361-369.

Vigouroux, Y., Barnaud, A., Scarcelli, N. \& Thuillet, A.C. (2011). Biodiversity, evolution and adaptation of cultivated crops. Comptes Rendus Biologies, 334(5-6), 450-457.

Walsh, F., Dobson, P.V., \& Douglas, J. (2013). Anpernirrentye: a Framework for Enhanced Application of Indigenous Ecological Knowledge in Natural Resource Management. Ecology and Society, 18(3), 18. Retrieved from http://www.ecologyandsociety.org/vol18/iss3/art18/.

Wang, J-X., Huang, J-K., \& Yan, T-T. (2013). Impacts of Climate Change on Water and Agricultural Production in Ten Large River Basins in China. Journal of Integrative Agriculture, 12(7), 1267-1278.

Wang, J-X., Huang, J-K., \& Yang, J. (2014). Overview of Impacts of Climate Change and Adaptation in China's Agriculture. Journal of Integrative Agriculture, 13(1), 1-17.

Webb, L., Bambrick, H., Tait, P., Green, D., \& Alexander, L. (2014). Effect of ambient temperature on Australian Northern Territory public hospital admissions for cardiovascular disease among Indigenous and non-Indigenous populations. International Journal of Environmental Research and Public Health, 11, 1942-1959. 
White, J.W., Hoogenboom, G., Kimball, B.A., \& Wall, G.W. (2011). Methodologies for simulating impacts of climate change on crop production. Field Crops Research, 124(3), 357-368.

Willows, R., \& Connell, R. (2003). Climate adaptation: Risk, uncertainty and decision-making: UK Climate Impacts Programme. Retrieved from http://environment.msu.edu/climatechange/UK_CC_ Decisions_Report.pdf

Wilson G.A. (2014). Community resilience: path dependency, lock in effects and transitional ruptures. Journal of Environmental Planning and Management, 57, 1-26.

Wise, R.M., Fazey, I., Stafford Smith, M., Park, S.E., Eakin, H.C., Archer Van Garderen, E.R.M., \& Campbell, B. (2014). Reconceptualising adaptation to climate change as part of pathways of change and response. Global Environmental Change, 28, 325-336.

Yohe, G., \& Leichenko, R. (2010). Chapter 2: Adapting a Risk Based Approach. In C. Rosenzweig \& W. Solecki (Eds.), Climate change adaptation in New York City: Building a risk management response (pp. 1191-1354). New York: Annals of the New York Academy of Sciences.

Zhou, L., \& Turvey, C.G. (2014). Climate change, adaptation and China's grain production. China Economic Review, 28, 72-89.

Zhou, Y., Zwahlen, F., Wang, Y. X., \& Li, Y. L. (2010). Impact of climate change on irrigation requirements in terms of groundwater resources. Hydrogeology Journal, 18(7), 1571-1582.

Zinyengere, N., Crespo, O., \& Hachigonta, S. (2013). Crop response to climate change in southern Africa: A comprehensive review. Global and Planetary Change, 111, 118-126.

Ziska, L.H., Bunce, J.A., Shimono, H., Gealy, D.R., Baker, J.T., Newton, P.C.D., Reynolds, M.P., Jagadish, K.S.V., Zhu, C.W., Howden, M., \& Wilson, L.T. (2012). Food security and climate change: on the potential to adapt global crop production by active selection to rising atmospheric carbon dioxide. Proceedings of the Royal Society B-Biological Sciences, 279(1745), 4097-4105. 
